Vol 13, Issue 6, 2020

\title{
NEUROPROTECTIVE EFFECT OF HYDROALCOHOLIC EXTRACT OF AMARANTHUS TRICOLOR LEAVES ON EXPERIMENTAL ANIMALS
}

\author{
VIDHAN CHAND BALA*, MOHD ABID \\ Department of Pharmacology, School of Pharmacy, IFTM University, Moradabad, Uttar Pradesh, India. \\ Email: vidhanchandbala07@gmail.com
}

Received: 18 February 2020, Revised and Accepted: 20 February 2020

\begin{abstract}
Objective: The research work deals with the screening of hydroalcoholic extract of Amaranthus tricolor (HAEATL) leaves for central nervous system activity (anti-stress, nootropic, and anti-cataleptic activity).

Methods: The screening of scopolamine and different model-induced neurodisorder rats were treated with 200 and 400 mg/kg body weight dose of hydroalcoholic extract of $A$. tricolor lives in 7 days' experimental schedule. It has been reported that the antioxidant, hepatoprotective, hematological, and antimicrobial activities.

Results: The result of the study reflected that HAEATL (200 and $400 \mathrm{mg} / \mathrm{kg}$ ) was effective in all methods and showed anti-stress, nootropic, and anti-cataleptic activity in a dose-dependent manner. The results are represented that the HAEATL produce the significant decreased the swimming time, increased the anoxia time, decreased level of biochemical parameters such as glucose and cholesterol except blood urea nitrogen, decreased level of white blood cell and red blood cell, and more significantly decreased the catalepsies score on $7^{\text {th }}$ day compared to the control group.
\end{abstract}

Conclusion: The above valuable animal study, we concluded that the HAEATL showing significantly affect compeer to the disease control group on neuroprotective activity.

Keyword: Amaranthus tricolor, Neuroprotective effect, Scopolamine, Anti-stress activity, Nootropic activity, Anti-cataleptic activity.

(C) 2020 The Authors. Published by Innovare Academic Sciences Pvt Ltd. This is an open access article under the CC BY license (http://creativecommons. org/licenses/by/4. 0/) DOI: http://dx.doi.org/10.22159/ajpcr.2020.v13i6.37181

\section{INTRODUCTION}

Stress is simply a reaction to a stimulus that disturbs our physical or mental equilibrium. Acute stress can be exciting; it keeps us active and alert, but chronic stress can have detrimental effects on health [1-3]. Memory function is at risk to many pathological conditions, including many neuropsychiatric and neurodegenerative diseases like Alzheimer's disease $[4,5]$. Nootropic drugs such as piracetam and cholinesterase inhibitors are clinically used to develop learning and memory capacity, mood, and behavior in those neurodegenerative diseases [6-8].

Parkinson's disease (PD) is a neurodegenerative disorder caused by the progressive loss of mesencephalic dopaminergic neurons in the substantia nigra innervating the striatum [9]. Recent research works demonstrated the development of PD up to a greater extent in animals [10].

Amaranthus tricolor L. is an adornment plant known as Tandalja or Tandalja Bhaji in India. In Andhra, it is ordinarily known as "Perugu Thotakura." The nutrients in the leaves are carbohydrates, protein, Vitamin A, Vitamin C, riboflavin (Vitamin B2), thiamine (Vitamin B1), niacin, and minerals such as $\mathrm{Ca}^{++}, \mathrm{Fe}$, and fiber [11]. The presence of betalain pigments such as amaranthine, $\beta$-xanthin, methyl derivative of arginine $\beta$-xanthin, and betalamic acid has been reported in leaves $[12,13]$.

The full plant of $A$. tricolor is conventionally used as astringent [14]. A. tricolor root combination with Cucurbita moschata used to manage post-abortion bleeding [15]. The cooked A. tricolor plant is utilized to strengthen the liver and promote the vision. The experimental research advises that it can inhibit calcium retention [16]. It was found that the plant possesses antioxidant [17], hepatoprotective [18], antinociceptive, and anti-inflammatory activities [19]. It is also reported for in vitro and in vivo anticancer effects [6], and in-vitro antioxidant, anti-amylase, anti-arthritic, and cytotoxic activity [20].

\section{MATERIALS AND METHODS}

Selection and verification of plant material

The raw A. tricolor (Amaranthaceae) plant was selected from selfcultivation in Moradabad region (Uttar Pradesh) India and verified by the Department of Botany, IFTM University, Moradabad - 244 001, Uttar Pradesh, India. No. - 2016/SOS/BOT/33.

\section{Investigation of plant material}

The dehydrated powder of $A$. tricolor was extracted with petroleum ether $60-800 \mathrm{C}$ to $72 \mathrm{~h}$. After petroleum ether extraction, marc is separated and dried at room temperature and then extracted with hydroalcoholic solvent ( $99 \% \mathrm{v} / \mathrm{v}$ alcohol + distilled water) to $72 \mathrm{~h}$ in Soxhlet apparatus. The extract was evaporated under reduced pressure which obtained a brownish-black color and a sticky residue. The sticky residue was used for identifying its activity on learning and memory activity.

\section{Chemicals and reagents}

All the chemicals and reagents used in this study were of analytical grade. Organic and inorganic solvent used for extraction of the plant material included: Chloroform, petroleum ether, potassium bismuth iodide solution, concentrated hydrochloric acid, sodium hydroxide, potassium mercuric iodide solution, copper sulphate, glacial acetic acid, sulfuric acid, n-butanol, a-napthol, n-hexane, and ethyl-acetate were collected in standard deviation (SD) fine chemicals Pvt. Chennai. 
Determination of extraction yield (\%yield)

The yield $(\% \mathrm{w} / \mathrm{w})$ from the dried extracts was calculated as:

$$
\text { Yield }(\%)=\frac{W 1}{W 2} \times 100
$$

Where, $w_{1}$ is the weight of dried extract after evaporation of solvent and $\mathrm{w}_{2}$ is the weight of plant powder.

\section{Phytochemical analysis}

Phytochemical screening test was done on a hydroalcoholic extract of A. tricolor leaves (HAEATL) extract that was determine by flavonoids, saponins, alkaloids, steroids and sterols amino acids, carbohydrates, protein, and tannin [21-23]

\section{Thin-layer chromatography (TLC)}

TLC is a separation, identification, and purification procedure that gives the chemist a quick answer as to how many components are in a mixture. It is also used to base on the identity of a compound in a mixture when the retention factor (RF) of a test compound is compared to the RF of a standard compound (preferably both run on the same TLC plate)

\section{Drugs and chemicals}

All conventional drugs like scopolamine hydrochloride, Bacopa manniri, sodium carboxymethyl cellulose (CMC Sodium), saline, test drugs and amnesia-inducing drugs (suspended in $0.5 \% \mathrm{w} / \mathrm{v}$ sodium $\mathrm{CMC}$ ) were administered in the morning session, i.e. from $10 \mathrm{am}$ to $11 \mathrm{am}$ on each day of the test period.

\section{Selection of experimental animals}

For both sexes healthy, young, 10-12-week-old Wistar albino rats weighing about 130-190 g, obtained from the animal house facility used for in vivo studies. The animal room should be maintained under normal ambient conditions (temperature $25^{\circ} \mathrm{C}$ and relative humidity $40-80 \%$ ) for $12 / 12 \mathrm{~h}$ of day/night cycle and fed with rat pellet and water ad libitum. Experimental protocol approved by the Institutional Animal Ethics Committee (IAEC) under IAEC Number - 837/PO/Re/S/04/CPCSEA.

\section{Experimental model}

Anti-stress activity

Different methods were used to evaluate the anti-stress activity of A. tricolor leaves.

Grouping of animals

Following group division will be considered for all the screening activities:

Group-I - Control group (vehicle $10 \mathrm{ml} / \mathrm{kg}$ pre os [p.o.])

Group-II - Stress control group (scopolamine $0.4 \mathrm{mg} / \mathrm{kg}$ intraperitoneal [i.p.])

Group-III - Low dose HAEATL $(200 \mathrm{mg} / \mathrm{kg}$ p.o. + scopolamine $0.4 \mathrm{mg} / \mathrm{kg}$ i.p.)

Group-IV - High dose HAEATL (400 mg/kg p.o. + scopolamine $0.4 \mathrm{mg} / \mathrm{kg}$ i.p.)

Group-V - Standard drug group (Withania somnifera $100 \mathrm{mg} / \mathrm{kg}$ p.o. + scopolamine $0.4 \mathrm{mg} / \mathrm{kg}$ i.p.).

\section{Swimming endurance test (SET)}

Stress was imposed on the rats by keeping them in cylindrical vessels (length $48 \mathrm{~cm}$ and width $30 \mathrm{~cm}$ ) filled with water to a height of $25 \mathrm{~cm}$ and the total swimming time for individual rats was noted, the rats were allowed to swim daily until exhausted, Wister albino rats (150$200 \mathrm{~g}$ ) were divided into four groups of six animals each. Group I is control, treated with vehicle (5 ml/kg p.o.), Group II and III treated with HAEATL (200 and $400 \mathrm{mg} / \mathrm{kg}$ p.o.), and Group IV treated with standard drug $W$. somnifera $(100 \mathrm{mg} / \mathrm{kg} \mathrm{p.o})$ was given to rats once daily for 7 days. On the $7^{\text {th }}$ day, $1 \mathrm{~h}$ after treatment, all the rats were subjected to SET. The rats were allowed to swim individually in a propylene tank, filled with water to a height of $25 \mathrm{~cm}$ maintained at room temperatures. The mean swimming time for each group was calculated [24].
Anoxia stress tolerance test (ASTT)

Wister albino rats (150-200 g) were divided into five groups of six animals each, grouping and treatment were similar as in SET. HAEATL or standard drug was given to the rats once daily for 7 days. On the $7^{\text {th }}$ day, $1 \mathrm{~h}$ after the treatment, stress was induced in all rats by placing each animal individually in a hermetic vessel of $500 \mathrm{ml}$ capacity to record anoxia tolerance time. The moment when the animal showed the first convulsions, it was immediately removed from the vessel and resuscitated if needed. The time duration between animal entry into the hermetic vessel and the appearance of the first convulsion was taken as the time of anoxia tolerance. Appearance of convulsion was a very sharp endpoint [25].

Immobilization stress test (IST)

In the immobilization stress model albino wistar rats were divided into five groups of six animals each. Group I is normal control, treated with vehicle ( $5 \mathrm{ml} / \mathrm{kg}$ p.o. control), Group II is stressed control treated with $(10 \mathrm{ml} / \mathrm{kg}$ p.o.), Group III and IV treated with HAEATL (200 and $400 \mathrm{mg} / \mathrm{kg}$ p.o.), and Group V treated with standard drug W. somnifera (100 mg/kg p.o.) was given to rats once daily for 7 days. The stress was produced by restraining the animals inside an adjustable acrylic hemicylindrical plastic tube ( $4.5 \mathrm{~cm}$ diameter, $12 \mathrm{~cm}$ long). The rats were confined individually and exposed continuously for a period of 150 min once daily for 7 consecutive days. On the $7^{\text {th }}$ day, immediately after the last exposure to stress, blood was collected from retro-orbital plexus under light ether anesthesia and serum and plasma were separated for biochemical estimation. The animals were sacrificed at the end of a specified period and the weights of organs were noted [13].

\section{Nootropic activity}

Different methods were used to evaluate the nootropic activity of A. tricolor leaves.

Grouping of animals

Following group division will be considered for all the screening activities:

Group-1 - Control group (vehicle $10 \mathrm{ml} / \mathrm{kg}$ p.o.)

Group-2 -Amnesia control group (scopolamine $0.4 \mathrm{mg} / \mathrm{kg}$ i.p.)

Group-3 - Low dose HAEATL $(200 \mathrm{mg} / \mathrm{kg}$ p.o. + scopolamine $0.4 \mathrm{mg} / \mathrm{kg}$ i.p.)

Group-4 - High dose HAEATL $(400 \mathrm{mg} / \mathrm{kg}$ p.o. + scopolamine $0.4 \mathrm{mg} / \mathrm{kg}$ i.p.)

Group-5 - Standard drug group (B. monnieri $100 \mathrm{mg} / \mathrm{kg}$ p.o. + scopolamine $0.4 \mathrm{mg} / \mathrm{kg}$ i.p.).

Elevated plus maze (EPM) test

An EPM comprising two open arms $(40 \mathrm{~cm} \times 12 \mathrm{~cm})$ crossed with two closed arms $(40 \mathrm{~cm} \times 12 \mathrm{~cm} \times 40 \mathrm{~cm})$ was used in this study to investigate the nootropic response. The arms were interconnected with a central square $(12 \mathrm{~cm} \times 12 \mathrm{~cm})$. The unit was raised to a height of $60 \mathrm{~cm}$ in dimly lit rooms. The EPM was placed inside the light and soundproofed room. Mice were placed separately on the open arm end of the EPM facing away from the midsection, and the time taken to move from the open arm to either of the closed arms was noted. Transfer latency (TL) was stored, which is considered as a parameter for evaluating the memory-enhancing property. TL was maintained over the period of time the mouse moved on one covered arm on all four legs, and TL was appoint for $90 \mathrm{~s}$. The mouse was allowed to examine the EPM for $10 \mathrm{~s}$ and then arrived to the home cage. Memory retention was examined $24 \mathrm{~h}$ after the $1^{\text {st }}$ day of the checkout (i.e., on day 2). On the $7^{\text {th }}$ day, 60 min after treatment with the last dose, a first test is administered and after $24 \mathrm{~h}$, a second test (i.e. on day 8) was observed. The inflection ratio (IR) was estimated using the formula.

$$
\mathrm{IR}=\frac{\mathrm{L} 0-\mathrm{L} 1}{\mathrm{~L} 0}
$$

Where $\mathrm{L} 0$ is the initial transmission latency (TL) per second for the first time, L1 is the TL per second for the second time. Decreased IR indicates the induction of amnesia and increased IR indicates an improvement in cognitive and memory impairment $[5,26]$. 
Morris water maze (MWM) test

The MWM presents a versatile element that can measure many different tasks for evaluating working memory in rats. MWM consists of a wide round container formed of black opaque PVC or solid cardboard, covered with fiberglass and resin, and then painted in white $(2-2.5 \mathrm{~m}$ in diameter and $0.5-0.6 \mathrm{~m}$ in height). The pool is filled with water $\left(20-25^{\circ} \mathrm{C}\right)$ to a depth of $0.5-0.6 \mathrm{~m}$ and made opaque by adding a limited amount of milk or milk powder or a non-toxic white color. The round tank floor is marked with four equal quarters, which are arbitrarily designed north, south, east, or west. The Escape Tray consists of plexiglass with a $12 \mathrm{~cm}$ square base fixed to a $34 \mathrm{~cm}$ long clear plexiglass, cylindrical base $(5 \mathrm{~cm}$ diameter) mounted in 1 $\mathrm{m}^{2}$ (5 mm thick) plexiglass. The top of the platform is covered with coarse material that provides the perfect grip for mice as they climb the platform. For the purpose of the hidden tray, water is added in a round container to a level $2 \mathrm{~cm}$ above the level.

The simplest measure of performance is the latency to escape from the water to a hidden substrate. The pad remains in a secure position during the exercise. Every animal is subjected to four consecutive examinations over a period of 4 days, during which they are granted to escape to a hidden level and remain there for $20 \mathrm{~s}$.

Escape latency (EL) is the amount of time that the location of the hidden platform in the MWM is stored as an acquisition or learning index. If the animal cannot locate the hidden substrate within $120 \mathrm{~s}$, it is carefully guided to the stage by hand and granted to remain there for $20 \mathrm{~s}$. On the $9^{\text {th }}$ day, 60 min after the last dose, the vessel is removed and each animal spent in the target quadrant searching for the hidden medium is recorded as a search index $[27,28]$.

\section{Cataleptic activity}

Grouping of animals

Following group division will be considered for all the screening activities:

Group-I - Control group (vehicles $10 \mathrm{ml} / \mathrm{kg}$ p.o.)

Group-II - Catalepsia control group (haloperidol $1 \mathrm{mg} / \mathrm{kg}$ i.p.)

Group-III - Low dose HAEATL (200 mg/kg. p.o. + haloperidol $1 \mathrm{mg} / \mathrm{kg}$ i.p.)

Group-IV - High dose HAEATL ( 400 mg/kg. p.o. + haloperidol $1 \mathrm{mg} / \mathrm{kg}$ i.p.)

Group-V - Standard drug group (Levodopa $5 \mathrm{mg} / \mathrm{kg}$ p.o. + haloperidol $1 \mathrm{mg} / \mathrm{kg}$ i.p.).

Haloperidol-induced Catalepsy

Haloperidol causes the defective function of various neurotransmitters such as acetylcholine, Gama aminobenzoic acid, and serotonin.

Table 1: Percent yield of Amaranthus tricolor leaf extracts

\begin{tabular}{llll}
\hline Extraction & $\begin{array}{l}\text { Solvents } \\
\text { used }\end{array}$ & Material & $\begin{array}{l}\text { Extract yield } \\
\text { (\%) }\end{array}$ \\
\hline HAE (maceration) & $\begin{array}{l}\text { Ethanol } \\
\text { HAE (soxhlation) }\end{array}$ & Dthanol powdered leaf & $5.6 \%$ \\
Dried powdered leaf & $7.3 \%$ \\
\hline
\end{tabular}

Table 2: Analysis for the presence of the different phytochemical compound in HAEATL

\begin{tabular}{ll}
\hline Constituent & HAEATL \\
\hline Flavonoids & + \\
Saponins & + \\
Alkaloids & + \\
Steroids and sterols & + \\
Amino acids & + \\
Carbohydrates & + \\
Protein & + \\
Tannins & + \\
\hline
\end{tabular}

+ = Present; - = Absent. HAEATL: Hydroalcoholic extract of Amaranthus tricolor leaves
Pathological state of haloperidol indicated catalepsy underlying increased oxidative stress. It is an antipsychotic drug, blocks central dopamine receptors in striatum. It also the production of a behavioral state in animals such as mice and rats, in which they fail to correct externally imposed postures (called catalepsy); thus, keeping the above fact in mind, the haloperidol-induced catalepsy model was selected. In this study, the animals were divided into five groups $(n=6)$. Group I served as vehicle control, Group II served negative control group no drugs, Groups III-VI served as test group treated with HAEATL (200 and $400 \mathrm{mg} / \mathrm{kg}$ p.o.), and Group V served as standard, levodopa ( $5 \mathrm{mg} / \mathrm{kg}$ p.o.), respectively. A standard bar test was used to measure the catalepsy. Catalepsy was induced by haloperidol $(1 \mathrm{mg} / \mathrm{kg}$ i.p.) and examined at every $30 \mathrm{~min}$ interval for $90 \mathrm{~min}$. The duration for which the rat retains the forepaws extended and resting on the elevated bar was considered as a cataleptic score. A cutoff time of 5 min was applied [29].

Behavioral studies

This scoring method was followed in three steps [30].

Step 1: The rat was taken out of the home cage and placed on a table. If the rat failed to move when touched or pushed gently on the back a score of 0.5 was assigned.

Step II: The front paws of the rats were placed alternately on a $3 \mathrm{~cm}$ high block. If the rat failed to correct the posture within $15 \mathrm{~s}$, a score of 0.5 for each paw was added to the score of step I.

Step III: The front paws of the rat were placed alternately on a $9 \mathrm{~cm}$ high block if the rat failed to correct the posture within $15 \mathrm{~s}$ a score

Table 3: The RF values of hydroalcoholic extract of Amaranthus tricolor leaves

\begin{tabular}{lll}
\hline No. & Band colour visible day light & RF values of test sample \\
\hline 1. & Yellow-green & 0.45 \\
2. & Green-brown & 0.5 \\
\hline
\end{tabular}

RF: Retention factor

Table 4: Effect of HAEATL on stress performance by swimming endurance test

\begin{tabular}{lll}
\hline S. No. & Treatment groups & $\begin{array}{l}\text { Swimming endurance } \\
\text { time in minutes }\end{array}$ \\
\hline 1. & Control group(vehicle $10 \mathrm{ml} / \mathrm{kg})$ & $18.50 \pm 0.806$ \\
2. & HAEATL $(200 \mathrm{mg} / \mathrm{kg})$ & $15.67 \pm 0.333^{*}$ \\
3. & HAEATL $(400 \mathrm{mg} / \mathrm{kg})$ & $14.67 \pm 0.557^{* *}$ \\
4. & Withania somnifera $(100 \mathrm{mg} / \mathrm{kg})$ & $13.50 \pm 0.806^{* * *}$ \\
\hline All values are mean \pm SD error. Statistical analysis of data was carried out by one- & way ANOVA followed by Dunnett's test. ns = not significant, ${ }^{*}<0.05,{ }^{* *}<0.01$, \\
and ${ }^{* *}$ p $<0.001$ when compared with control group. HAEATL: Hydroalcoholic \\
extract of Amaranthus tricolor leaves, SD: Standard deviation
\end{tabular}

Table 5: Effect of HAEATL on stress performance by anoxia stress tolerance test

\begin{tabular}{lll}
\hline S. No. & Treatment groups & $\begin{array}{l}\text { Duration of anoxia } \\
\text { stress tolerance in } \\
\text { minutes }\end{array}$ \\
\hline 1. & Control group (vehicle $10 \mathrm{ml} / \mathrm{kg})$ & $18.83 \pm 0.401$ \\
2. & HAEATL $(200 \mathrm{mg} / \mathrm{kg})$ & $21.67 \pm 0.614^{\mathrm{ns}}$ \\
3. & HAEATL $(400 \mathrm{mg} / \mathrm{kg})$ & $22.67 \pm 0.557^{* *}$ \\
4. & Withania somnifera $(100 \mathrm{mg} / \mathrm{kg})$ & $25.00 \pm 1.291^{* * *}$ \\
\hline All values are mean \pm SD error. Statistical analysis of data was carried out by \\
one-way ANOVA followed by Dunnett's test. ns = not significant, ${ }^{* *}$ p $<0.01$, \\
and ${ }^{* * *}$ p $<0.001$ when compared with control group. HAEATL: Hydroalcoholic \\
extract of Amaranthus tricolor leaves, SD: Standard deviation
\end{tabular}


Table 6: Effect of HAEATL on biochemical parameters in the immobilization stress test

\begin{tabular}{llll}
\hline S. No. & Treatment group & \multicolumn{2}{l}{ Biochemical parameter } \\
\cline { 3 - 4 } & & Glucose & Cholesterol \\
\hline 1. & Control group (vehicle $10 \mathrm{ml} / \mathrm{kg})$ & $62.00 \pm 0.730$ & $67.53 \pm 0.111$ \\
2. & Stress control group & $139.2 \pm 1.102$ & $72.60 \pm 0.162$ \\
3. & HAEATL $(200 \mathrm{mg} / \mathrm{kg})$ & $97.00 \pm 1.317^{* * *}$ & $69.81 \pm 0.166^{* * *}$ \\
4. & HAEATL $(400 \mathrm{mg} / \mathrm{kg})$ & $72.67 \pm 0.918^{* * *}$ & $42.47 \pm 0.095^{* * *}$ \\
5. & Withania somnifera $(100 \mathrm{mg} / \mathrm{kg})$ & $83.67 \pm 0.557^{* * *}$ & $15.27 \pm 0.378$ \\
\hline
\end{tabular}

All values are mean \pm SD error. Statistical analysis of data was carried out by one-way ANOVA followed by Dunnett's test. ns $=$ not significant, ${ }^{*} \mathrm{p}<0.05$, $* * \mathrm{p}<0.01$, and

${ }^{* * *} \mathrm{p}<0.001$ when compared with stress control group. HAEATL: Hydroalcoholic extract of Amaranthus tricolor leaves, SD: Standard deviation

Table 7: Effect of HAEATL on hematological parameters in the immobilization stress test

\begin{tabular}{llll}
\hline S. No. & Treatment & \multicolumn{2}{l}{ Hematological parameters } \\
\cline { 3 - 4 } & & Total WBC & Total RBC \\
\hline 1. & Control group vehicle & $7445 \pm 115.30$ & $6.107 \pm 0.03$ \\
& $(10 \mathrm{ml} / \mathrm{kg})$ & & \\
2. & Stressed control group & $11472 \pm 248.10$ & $4.44 \pm 0.09$ \\
3. & HAEATL (200 mg/kg) & $9157 \pm 64.01^{* * *}$ & $5.153 \pm 0.07^{* * *}$ \\
4. & HAEATL (400 mg/kg) & $8087 \pm 108.30^{* * *}$ & $5.400 \pm 0.11^{* * *}$ \\
5. & Withania somnifera & $7777 \pm 60.09^{* * *}$ & $5.775 \pm 0.02^{* * *}$ \\
& $(100 \mathrm{mg} / \mathrm{kg})$ & & \\
\hline
\end{tabular}

All values are mean \pm SD error. Statistical analysis of data was carried out by one-way ANOVA followed by Dunnett's test. ns = not significant, ${ }^{*} \mathrm{p}<0.05,{ }^{*} \mathrm{p}<0.01$, and ${ }^{* *} \mathrm{p}<0.001$ when compared with stress control group. HAEATL: Hydroalcoholic extract of Amaranthus tricolor leaves, WBC: White blood cell, RBC: Red blood cell, SD: Standard deviation

of 1 for each paw was added to the scores of steps I and II. Thus, the highest score for any animal was 3.5 (cut off score) and that reflects total catalepsy [31,32].

\section{RESULTS}

\section{Determination of percentage (\%) yield}

Table 1 gives the percent yield of leaf extracts of $A$. tricolor obtained using various solvents/techniques. The hydroalcoholic (ethanol+distril water) extracts obtained were dark reddish-brown and semisolid in consistency.

\section{Qualitative phytochemical analysis}

The different phytochemical tests carried out for a screening of various chemical constituents of $A$. tricolor leaves. The phytochemical tests indicated the presence of proteins, amino acids, tannins, polyphenols, sterols, flavonoids, and polyphenol in the HAEATL as results are shown in Table 2.

\section{Chromatographic studies}

$T L C$

TLC of the hydroalcoholic extract in hexane: chloroform:ethyl acetate (1:3:3) solvent system yielded two visible spots. Distance travel by solvent $6.2 \mathrm{~cm}$ distances between first sport $2.8 \mathrm{~cm}$ and second sport $3.1 \mathrm{~cm}$ on exposure to visible daylight and iodine vapors a total of 2 spots could be visualized (Table 3).

\section{Anti-stress activity}

SET

In SET, HAEATL $(200 \mathrm{mg} / \mathrm{kg})$ significantly $(P<0.05)$ decreased the swimming time, whereas HAEATL $(400 \mathrm{mg} / \mathrm{kg})$ significantly $(P<0.01)$ and standard drug $W$. somnifera $(100 \mathrm{mg} / \mathrm{kg})$ more significantly $(P<0.001)$ decreased the swimming time compared to the control group as the results are shown in Table 4.
ASTT

The results are represented that the HAEATL $(200 \mathrm{mg} / \mathrm{kg})$ did produce a significant effect. HAEATL $(400 \mathrm{mg} / \mathrm{kg})$ significantly $(P<0.01)$ and standard drug $W$. somnifera $(100 \mathrm{mg} / \mathrm{kg})$ more significantly $(P<0.001)$ increased the anoxia time on $7^{\text {th }}$ day compared to the control group. High dose $(400 \mathrm{mg} / \mathrm{kg})$ and standard drug $(100 \mathrm{mg} / \mathrm{kg})$ were found to be comparable effective in this test as the results are shown in Table 5.

\section{Immobilization stress \\ Biochemical parameters}

In this test, HAEATL $(200 \mathrm{mg} / \mathrm{kg})$ showed significant $(P<0.001)$ effect of glucose and cholesterol level but blood urea nitrogen (BUN) is did not significantly affect whereas HAEATL $(400 \mathrm{mg} / \mathrm{kg})$ and standard drug W. somnifera $(100 \mathrm{mg} / \mathrm{kg})$ more significantly $(P<0.001)$ decreased level of biochemical parameters such as glucose and cholesterol except BUN, $400 \mathrm{mg}$ significantly $(P<0.01)$ and standard drug $W$. somnifera $(100 \mathrm{mg} / \mathrm{kg})$ more significantly $(P<0.001)$ increased as compared to the stressed control group. Both standard $(100 \mathrm{mg} / \mathrm{kg})$ and high dose $(400 \mathrm{mg} / \mathrm{kg}$ ) drug showed an almost similar effect as the results are shown in Table 6.

\section{Hematological parameters}

In this test, HAEATL $(200 \mathrm{mg} / \mathrm{kg})$ showed significant effect whereas HAEATL $(400 \mathrm{mg} / \mathrm{kg})$ and standard drug W. somnifera $(100 \mathrm{mg} / \mathrm{kg})$ more significantly $(P<0.001)$ decreased level of white blood cell and red blood cell more significantly $(P<0.001)$ increased, compared to the stressed control group. Both standard and HAEATL ( $400 \mathrm{mg} / \mathrm{kg}$ ) drugs showed almost similar effects as the results are shown in Table 7.

\section{Organ weights}

In this test, HAEATL $(200 \mathrm{mg} / \mathrm{kg})$ did not significantly measure weight of liver and significantly $(P<0.01)$ decreased weight of adrenal gland but more significantly $(P<0.001)$ increased weight of spleen, whereas HAEATL $(400 \mathrm{mg} / \mathrm{kg})$ and standard drug $W$. somnifera $(100 \mathrm{mg} / \mathrm{kg})$ more significantly $(P<0.001)$ decreased the body organ weights of liver and adrenal gland but the more significantly $(P<0.001)$ increased weight of spleen as compared to the stressed control group, the results are shown in Table 8.

\section{Nootropic activity}

$E P M$

In this test, HAEATL $(200 \mathrm{mg} / \mathrm{kg})$ significantly $(P<0.05)$ and HAEATL $(400 \mathrm{mg} / \mathrm{kg})$ significantly $(P<0.01)$ reduced the memory of the standard group (B. monnieri $100 \mathrm{mg} / \mathrm{kg}$ ) demonstrated a significant decrease in TL compared to the AC control group as the results are shown in Table 9.

\section{$M W M$}

In this test, HAEATL $(200 \mathrm{mg} / \mathrm{kg})$ did not significantly increase EL, whereas HAEATL $(400 \mathrm{mg} / \mathrm{kg})$ significantly $(P<0.01)$ and the standard group (B. monnieri $100 \mathrm{mg} / \mathrm{kg}$ ) significantly $(P<0.001)$ increased EL compared to the $\mathrm{AC}$ control group because the results are presented in Table 10. 
Table 8: Effect of HAEATL on immobilization stress-induced changes in organ weight

\begin{tabular}{|c|c|c|c|c|}
\hline \multirow[t]{2}{*}{ S. No. } & \multirow[t]{2}{*}{ Treatment groups } & \multicolumn{3}{|c|}{ Organ weight (g/100 g body weight) } \\
\hline & & Liver & Adrenal gland & Spleen \\
\hline 1. & Control group (vehicle $10 \mathrm{ml} / \mathrm{kg}$ ) & $3.26 \pm 0.100$ & $0.03 \pm 0.002$ & $0.35 \pm 0.003$ \\
\hline 3. & HAEATL (200 mg/kg) & $5.56 \pm 0.167^{\mathrm{ns}}$ & $0.06 \pm 0.002^{* *}$ & $0.34 \pm 0.003^{* * *}$ \\
\hline 4. & HAEATL (400 mg/kg) & $4.98 \pm 0.336^{* * *}$ & $0.05 \pm 0.002^{* * *}$ & $0.32 \pm 0.004^{* * *}$ \\
\hline 5. & Withania somnifera $(100 \mathrm{mg} / \mathrm{kg})$ & $4.15 \pm 0.019 * * *$ & $0.05 \pm 0.003^{* * *}$ & $0.39 \pm 0.003^{* * *}$ \\
\hline
\end{tabular}

Table 9: Effect of HAEATL on learning performance by plus-maze test

\begin{tabular}{|c|c|c|c|c|}
\hline S. No. & Treatment group & Transfer latency $7^{\text {th }}$ day & Transfer latency after $24 \mathrm{~h}$ & Inflection ratio (IR) \\
\hline 1. & Control group (vehicle $10 \mathrm{ml} / \mathrm{kg}$ ) & $16.17 \pm 1.66$ & $13.62 \pm 1.52$ & $0.16 \pm 0.02$ \\
\hline 2. & AC control group (scopolamine) & $23.50 \pm 1.68$ & $30.33 \pm 1.85$ & $0.29 \pm 0.01$ \\
\hline 3. & HAEATL (200 mg/kg + scopolamine) & $16.50 \pm 0.42$ & $14.17 \pm 0.60^{* *}$ & $0.12 \pm 0.03$ \\
\hline 4. & HAEATL (400 mg/kg + scopolamine) & $13.67 \pm 0.88$ & $11.83 \pm 0.94^{* * *}$ & $0.13 \pm 0.03$ \\
\hline 5. & Bacopa monnieri $(100 \mathrm{mg} / \mathrm{kg})+$ scopolamine & $12.50 \pm 0.61$ & $10.67 \pm 0.42^{* * *}$ & $0.14 \pm 0.01$ \\
\hline
\end{tabular}

All values are means \pm SD error. Statistical analysis of the input was performed by one-way ANOVA followed by Dunnett's test. ns $=$ not significant, ${ }^{*} \mathrm{p}<0.05,{ }^{* *} \mathrm{p}<0.01$, and ${ }^{* * *} \mathrm{p}<0.001$ compared to the AC control group. HAEATL: Hydroalcoholic extract of Amaranthus tricolor leaves, SD: Standard deviation

Table 10: Effect of HAEATL on learning performance by water maze model

\begin{tabular}{lllll}
\hline S. No. & Treatment group & Escape latency $\mathbf{7}^{\text {th }}$ day & Escape latency after $\mathbf{2 4 ~ h}$ & Inflection ratio (IR) \\
\hline 1. & Control group (vehicle $10 \mathrm{ml} / \mathrm{kg})$ & $15.83 \pm 0.07$ & $11.00 \pm 0.25$ & $0.28 \pm 0.04$ \\
2. & AC control group (scopolamine) & $24.50 \pm 0.80$ & $40.83 \pm 1.24$ & $0.006 \pm 0.00$ \\
3. & HAEATL (200 mg/kg + scopolamine) & $20.00 \pm 0.96$ & $17.50 \pm 1.11^{* * *}$ & $0.12 \pm 0.02$ \\
4. & HAEATL (400 mg/kg + scopolamine) & $19.17 \pm 0.60$ & $15.83 \pm 0.74^{* * *}$ & $0.16 \pm 0.03$ \\
5. & Bacopa monnieri (100 mg/kg)+scopolamine & $17.33 \pm 1.17$ & $13.67 \pm 0.76^{* * *}$ & $0.19 \pm 0.04$ \\
\hline
\end{tabular}

All values are means \pm SD error. Statistical analysis of the input was performed by one-way ANOVA followed by Dunnett's test. ns $=$ not significant, ${ }^{*} \mathrm{p}<0.05$,

${ }^{* *} \mathrm{p}<0.01$, and ${ }^{* * *} \mathrm{p}<0.001$ compared to the AC control group. HAEATL: Hydroalcoholic extract of Amaranthus tricolor leaves, SD: Standard deviation

Table 11: Effect of HAEATL on catalepsies performance by behavioral studies

\begin{tabular}{|c|c|c|c|c|}
\hline \multirow[t]{2}{*}{ S. No. } & \multirow[t]{2}{*}{ Treatment groups } & \multicolumn{3}{|c|}{ Catalepsy score after haloperidol administration } \\
\hline & & $30 \mathrm{~min}$ & $60 \mathrm{~min}$ & $90 \mathrm{~min}$ \\
\hline 1. & Control group (vehicle 10 ml/kg) & $0.00 \pm 0.00$ & $0.00 \pm 0.00$ & $0.00 \pm 0.00$ \\
\hline 2. & Catalepsia control group (haloperidol $2 \mathrm{mg} / \mathrm{kg}$ ) & $3.5 \pm 0.00$ & $3.5 \pm 0.00$ & $3.5 \pm 0.00$ \\
\hline 3. & HAEATL (200 mg/kg + haloperidol $2 \mathrm{mg} / \mathrm{kg}$ ) & $2.25 \pm 0.11^{* * *}$ & $2.41 \pm 0.15^{* * *}$ & $2.85 \pm 0.10^{* *}$ \\
\hline 4. & HAEATL (400 mg/kg + haloperidol $2 \mathrm{mg} / \mathrm{kg}$ ) & $1.58 \pm 0.37^{* * *}$ & $2.16 \pm 0.10^{* * *}$ & $2.25 \pm 0.17^{* * *}$ \\
\hline 5. & Standard group (levodopa + carbidopa $10 \mathrm{mg} / \mathrm{kg}$ + haloperidol $2 \mathrm{mg} / \mathrm{kg}$ ) & $1.33 \pm 0.24^{* * *}$ & $1.33 \pm 0.10^{* * *}$ & $1.97 \pm 0.15^{* * *}$ \\
\hline
\end{tabular}

\section{Anti-cataleptic activity}

Behavioral studies

The results are represented that the HAEATL $(200 \mathrm{mg} / \mathrm{kg})$ more significantly $(P<0.001)$ decreased the catalepsies score after $30 \mathrm{~min}$, $60 \mathrm{~min}$, and $90 \mathrm{~min}$. Haloperidol administration HAEATL ( $400 \mathrm{mg} / \mathrm{kg}$ ) and standard drug Syndopa (levodopa+carbidopa $10 \mathrm{mg} / \mathrm{kg}$ ) more significantly $(P<0.001)$ decreased the catalepsies score on $7^{\text {th }}$ day compared to the CC control group. High dose $(400 \mathrm{mg} / \mathrm{kg})$ and standard drug $(100 \mathrm{mg} / \mathrm{kg})$ were found to be comparable effective in this test as the results are shown in Table 11.

\section{DISCUSSION}

Learning has been defined as the process of obtaining the knowledge while memory in mind retention of knowledge that can be saved. In the plus-maze acquisition (learning), it can be expected to be latent (TL) in the $7^{\text {th }}$-day assay and retention/consolidation (memory) is examined $24 \mathrm{~h}$ later, i.e., on the $8^{\text {th }}$ day after treatment with the test compound. TL increased in AC control group, i.e., scopolamine treated group. Amnesia has been noticed after the treatment. After day 7 of treatment, HAEATL $(200-400 \mathrm{mg} / \mathrm{kg})$ had a significant $(P<0.01)$ reduction in memory transfer delay. The standard group (B. monnieri $100 \mathrm{mg} / \mathrm{kg}$ ) showed a more significant $(P<0.001)$ decrease in transmission latency compared to the AC control group (IR $0.03 \pm 0.006$ ). Reduce TL (treatment group) showed protection against memory loss and impaired cognition. MWM learning is a reasonably good test for cognitive function. The exit delay was increased using MWM. Exit delay increased in extract and B. monnieri treated group due to cognitive function.

\section{CONCLUSION}

The above valuable animal study, we concluded that the HAEATL showing significantly affect compeer to the disease control group, on anti-stress, nootropic, and anti-Alzheimer activity. Hence, research calculates that $A$. tricolor has the capacity for management of central nervous system (CNS) disorder as it shows the effect on almost all the medals. It can be used for the reduction of side effects of drugs currently available in market. 
However, further studies are necessary to examine underlining mechanisms of CNS effect of different fraction of potent extract and to isolate the active compound responsible for these pharmacological activities.

\section{ACKNOWLEDGMENT}

My work cannot be completed by the grace of God, so I pay deep sense of gratitude to the almighty who blessed me with patience and dynamism to complete this work. I would like to express my deep sense of gratitude to all those who helped me directly and indirectly in completing this thesis work. I am heartfelt thankful to my guide Mr. Mohd. Abid to given me his priceless time and support for awarding me supervision and real interest in my research work and completing my thesis nicely. I express my deep gratefulness to Prof. Dr. Ashok Kumar Ghosh Director of School of Pharmaceutical Sciences, for providing the facilities, co-operation guidance, and independence for my research work

\section{AUTHORS' CONTRIBUTIONS}

All authors have an equal contribution.

\section{CONFLICTS OF INTEREST}

The authors do not have any conflicts of interest.

\section{AUTHORS' FUNDING}

The authors do not have any source of funding.

\section{REFERENCES}

1. Pawar VS, Hugar S. Acurrent status of adaptogens: Natural remedy to stress. Asian Pac J Trop Dis 2012;1:480-90.

2. Kumar N. Developments in mental health scenario: Need to stop exclusion-dare to care. ICMR Bull 2001;31:1-10.

3. Gaziano T, Chaturvedi V, Raddy KS, Paccaud F, Horton S. Cardiovascular Disease. Disease Control Priorities in Developing Countries. $2^{\text {nd }}$ ed. Oxford: Oxford University Press; 2006. p. 2012-18.

4. Dinesh D, Milind P, Kulkarni SK. Memory enhancing activity of Glycyrrhiza glabra in mice. J Ethnopharmacol 2004;9:361-5.

5. Hanumanthachar J, Milind P. Nootropic activity of calyces of Hibiscus sabdariffa Linn. Iran J Pharmacol Ther 2006;5:15-20.

6. Sani D, Sanni SN, Ngulde I. Phytochemical and antimicrobial screening of the stem aqueous extract of Anisopus mannii. J Med Plants Res 2009;3:112-5

7. Hanumanthachar J, Milind P. Pharmacological evidences for the ant amnesic effects of Desmodium gangeticum in mice. Iran J Pharm Res 2007:1:199-07.

8. Muraleedharannair JM, Johnson MA, Mony M, Zachariah MP, Solomon J, Phytochemical studies on Azolla pinnata $\mathrm{R}$. Br, Marsilea minuta L. and Salvinia molesta Mitch. Asian Pac J Trop Biomed 2011;1:26-9.

9. Alexi T, Borlongan CV, Faull LM, Williams CE, Clark GR, Gluckman PD. Neuroprotective strategies for basal ganglia degeneration, Parkinson's and Huntington's diseases. Prog Neurobiol 2000;5:409-70.

10. Przedborski S, Tieu K, Perier C, Vila M. MPTP as a mitochondrial neurotoxin model of Parkinson's disease. J Bioenerg Biomembr
2004;36:375-9.

11. Bala VC, Avid M, Kumar P, Sangam. A review on Amaranthus tricolor as a traditional medicinal plant. World J Pharm Res 2019;8:226-37.

12. Mousumi B, Satyahari D, Ramakrishna S. Betalains from Amaranthus tricolor L. J Pharmacogn Phytochem 2013;1:87-95.

13. Rai D, Bhatia G, Sen T, Palit G. Anti-stress effects of Ginkgo biloba and Panax ginseng. A comparative study. J Pharmacol Sci 2003;93:458-4.

14. Chopra RN, Nayar SL, Chopra IC. Glossary of Indian Medicinal Plants. New Delhi: Council of Scientific and Industrial Research; 1956.

15. Duke J, Ayensu ES. Medicinal Plants of China. Vol. 1. Algonac, Mich: Reference Publications, Inc.; 1985. p. 20-4

16. Larsen T, Thilsted SH, Biswas SK, Tetens I. The leafy vegetable amaranth (Amaranthus gangeticus) is a potent inhibitor of calcium availability and retention in rice-based diets. Br J Nutr 2007;1:521-7.

17. Samsul K, Krupanidhi K, Rao KR. Evaluation of in-vitro antioxidant activity of Amaranthus tricolor Linn, Asian J Pharmacol Toxicol 2013:1:12-6.

18. Simran MV, Sushma A, Satish S. Phytochemistry and hepatoprotective activity of aqueous extract of Amaranthus tricolor (Linn.) roots. J Ayurveda Integer Med 2013;4:211-5.

19. Gopal VB, Subhash LB, Parag PK, Girish NZ. Anti-nociceptive and anti-inflammatory activity of hydroalcoholic extract of leaves of Amaranthus tricolor L. Scholars Res Lib 2013;5:48-55.

20. Kumar V. In-vitro anti-oxidant, anti-amylase, anti-arthritic and cytotoxic activity of important commonly used green leafy vegetables. Int J PharmTech Res 2011;3:2096-103.

21. Evans WC. Trease and Evans Pharmacognosy. $5^{\text {th }}$ ed. Mumbai: Harcourt Publisher Limited; 2002. p. 262-3.

22. Kokate CK, Purohit AP, Gokhale SB. Pharmacognosy. $20^{\text {th }}$ ed. Pune: Nirali Prakashan; 2002. p. 108-9.

23. Shil D, Laloo D, Das SR, Dash S. Pharmacognostical and phytochemical standardization of Physalis minima leaf. Int J Pharm Pharm Sci 2020;11:20-5

24. Ahmad G, Amin KM, Khan NA. The anti-stress activity of a gem-containing unani formulation against diverse stressors. J Ethanopharmacol 1998;59:187-3.

25. Babu PV, Rao MA, Kumar SM, Rao NV. A study on adaptogenic activity of tuber extracts of Pueraria tuberosa. Indian Drugs 2006;43:486-2.

26. Rao VN, Pujar B, Nimbal SK, Shantakumar SM, Satyanarayana S. Nootropic activity of tuber extract of Pueraria tuberosa (roxb). Indian J Exp Biol 2008;46:591-8.

27. Rahman H, Muralidharan P. Nardostacys jatamansi protects from the loss of memory and cognition deficits in sleep deprived Alzheimer's disease mice model. Int J Pharm Sci Rev Res 2010;5:160-7.

28. Kshirsagar SN. Nootropic activity of dried seed kernels of Caesalpinia crista against scopolamine induced amnesia in mice. Int J PharmTech Res 2011:1:104-9.

29. Elliott PJ, Close SP. Neuroleptic-induced catalepsy as a model of Parkinson's disease. Effect of dopaminergic agents. J Neural Transm Park Dis Dement Sect 1990;2:79-89.

30. Kulkarni SK. Handbook of Experimental Pharmacology. $3^{\text {rd }}$ ed. New Delhi: Vallabh Prakashan; 1999. p. 125-6.

31. Rout S, Rath B, Bhattamisra SK, Kumar A, Rath S. Neuroprotective effect of methanolic extract of Sargassum wightii on haloperidol induced catalepsy and tardive dyskinesia in albino rats. Int J Pharm Pharm Sci 2020;12:1-6.

32. Sharma N, Rana AC, Bafna P. Effect of aqueous extract of Cynodon dactylon on reserpine induced catalepsy. Int J Pharm Pharm Sci 2011;3:424-6. 